\title{
Surgical treatment of bisphosphonate-associated osteonecrosis of the mandible: Report of two cases
}

\author{
Mandibulada bifosfonat kullanımı sonucunda oluşan osteonekrozun cerrahi tedavisi: iki vaka \\ raporu
}

İzzet Acikan ${ }^{1}$, Necat Aslan ${ }^{1}$, Halil ibrahim Durmuş ${ }^{1}$, Yusuf Atalay², Serhat Atlgan ${ }^{1}$, Ferhan Yaman ${ }^{1}$

\begin{abstract}
Bisphosphonates are used to reduce skeletal-related events in patients with bone-consuming diseases, such as osteoporosis and bone metastases. Bisphosphonaterelated osteonecrosis of the jaw (BRONJ) is becoming increasingly common with increasing use of bisphosphonates. We present two cases of BRONJ in a 64-year-old female and a 56-year-old female who were admitted to our department with complaints of purulent discharge and pain of the lower jaw. Both patients had been taking bisphosphonate and were diagnosed with jaw osteonecrosis, which can occur due to long-term use of bisphosphonate. The patients underwent medical treatment, including chlorhexidine rinses and antibiotics. Bone debridement was then performed under local anaesthesia. Both patients recovered well. There are many protocols, guidelines and suggestions on the management of BRONJ. For most patients, a conservative approach with minimal local intervention, if necessary, is appropriate, with extensive debridement of necrotic bone when this fails. In a small number of cases, radical resection of bone and reconstruction may be required. J Clin Exp Invest 2015; 6 (1): 61-64
\end{abstract}

Key words: Osteonecrosis, Bisphosphonate, jaw

\section{INTRODUCTION}

Bisphosphonates are used to reduce skeletal-related events in patients with bone-consuming diseases, such as osteoporosis and bone metastases [1]. Recently, there has been an increased awareness of bisphosphonate-related necrosis of the jaw (BRONJ) [1]. With increasing use of bisphosphonates, this complication is now encountered more frequently [2]. Patients taking bisphosphonate may

\section{ÖZET}

Bifosfonatlar osteoporoz ve kemik metastazı gibi hastalıklardaki kemik yıkımını azaltmaktadır. Artan bifosfonat kullanımıyla birlikte çenelerde görülen bifosfonatla ilişkili osteonekrozda yaygınlaşmaktadır. Kliniğimize alt çenede püy akıntısı ve ağrı şikayeti ile başvuran 64 ve 56 yaşında iki bayan hastanın bifosfonat kullanımıyla ilişkili osteonekroz vakalarını sunuyoruz. Her iki vakada uzun dönem bifosfonat kullanımına bağlı osteonekroz teşhisi konuldu. Tıbbi ve cerrahi tedavi planlaması yapıldı. Hastalara Klorheksidin irrigasyonu ve antibiyotik reçete edildi. Daha sonra lokal anestezi altında kemik debridmanı yapıldı. Her iki hastada çok iyi iyileşme görüldü. Bifosfonatla ilgili osteonekroz tedavisi için önerilen çok sayıda protokol bulunmaktadır. Çoğu hastada konservatif bir yaklaşım olarak nekrotik kemiğin geniş debridmanı ve küçük lokal girişimler yeterlidir ancak çok az vakada bu girişimler başarısız olursa radikal olarak kemiği rezeke etmek gerekmektedir.

Anahtar kelimeler: Osteonekroz, bifosfonat, çene

develop bisphosphonate-associated osteonecrosis after dento-alveolar surgery or trauma of the oral mucosa [3]. Appropriate approaches for the prevention and treatment of BRONJ have not been established [3]. One reason is the poor understanding of the pathogenesis of bisphosphonate-associated osteonecrosis [3]. We describe two cases of bisphosphonate-associated osteonecrosis who were treated with a combination of medical and surgical modalities.

\footnotetext{
${ }^{1}$ Dicle University, Faculty of Dentistry, Department of Oral and Maxillofacial Surgery Diyarbakır, Turkey

${ }^{2}$ Afyon Kocatepe University, Faculty of Dentistry, Department of Oral and Maxillofacial Surgery, Afyon, Turkey
}

Correspondence: i̇zzet Acıkan,

Dicle University, Faculty of Dentistry, Dept. Oral and Maxillofacial Surgery, Diyarbakır, Turkey Email: izzetacikan@hotmail.com 


\section{CASE 1}

A 64-year-old female who has been taking bisphosphonate (5 $\mathrm{mg}$ of risedronate sodium daily) for about 5 years for osteoporosis was admitted to our department with the complaint of lower jaw pain. On physical examination, the mucosa of the left posterior mandible was red and there was a large area of exposed necrotic bone of the left posterior mandible. A purulent discharge was also present (Fig. 1). Panoramic radiography revealed sclerosis
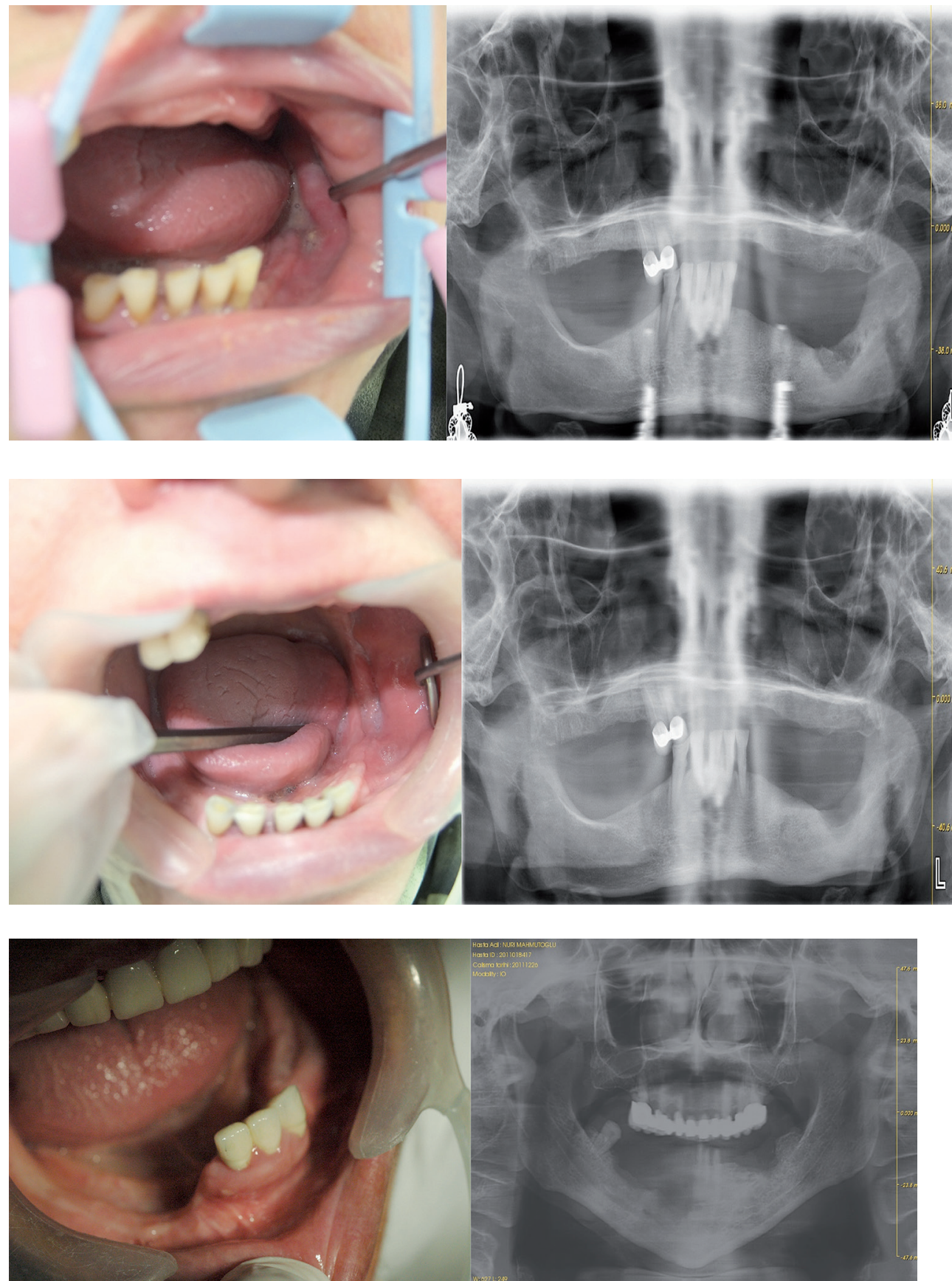

and a moth-eaten appearance at the inferior aspect of the left posterior mandible (Figure 1). In light of these findings, the lesion was diagnosed as stage 2 BRONJ. Surgical and medical treatment was planned, and the risedronate sodium was stopped for 3 months prior to the surgery. Chlorhexidine rinses and antibiotics were prescribed for 2 weeks. The patient then underwent bone debridement under local anaesthesia. Her symptoms had improved on follow-up 5 months later (Figure 2).
Figure 1. Case 1 preoperative intraoral view and panoramic radiography

Figure 2. Case1 preoperative intraoral view and panoramic radiography (about 5 mounts later)

Figure 3. Case 2 preoperative intraoral view and panoramic radiography 


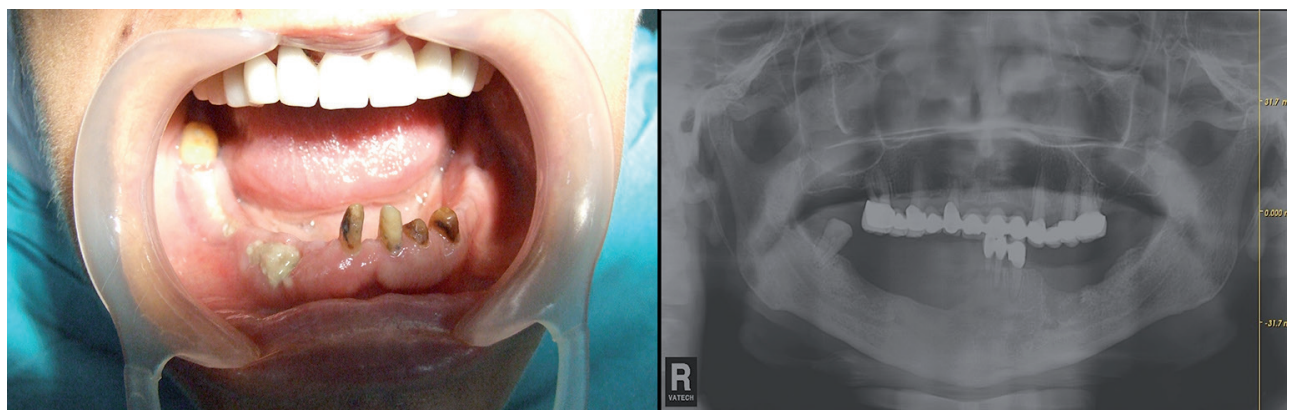

Figure 4. Case 2 preoperative intraoral view and panoramic radiography (about one year later)

\section{CASE 2}

A 56-year-old female who had an approximately 3 -year history of bisphosphonate use $(10 \mathrm{mg}$ of alendronic acid daily) for osteoporosis was referred to our clinic with the compliant of purulent discharge of the lower jaw. A physical examination revealed a purulent discharge in the right and left molar area of the mandible (Fig. 3). Diffuse osteolysis of the right and left mandibular body and a sequestrum near the alveolar crest were detected on panoramic radiography (Fig. 3). The patient was diagnosed with stage 2 jaw osteonecrosis, with secondary infection, likely due to the long-term use of bisphosphonate. The treatment comprised surgical debridement, antibiotic use and a drug holiday (discontinuation of alendronate for 3 months before the surgery). At 1 -year follow-up, the patient showed a good recovery (Fig. 4).

\section{DISCUSSION}

Osteonecrosis of the mandible has multiple etiologies, but it is most commonly seen following radiation therapy for head and neck malignancies [4]. The development of mandibular osteonecrosis with bisphosphonate use is well established [5]. Changes in bone metabolism following bisphosphonate using trauma are seem to be key factors in the development of osteonecrosis. Osteonecrosis may appear as dental abscesses, toothaches, denture sore spots or osteomyelitis. A tooth extraction is the most common trigger [6], although there have been cases of lesions arising spontaneously in areas not subjected to dental extractions [2].

BRONJ is classified into four stages. In stage 0 , symptoms and signs of pain or radiological findings are not present. Stage 1 includes asymptomatic bone exposure. In stage 2, there is exposed bone, together with pain and infection. Patients with stage 3 diseases have exposed bone, pain, infection and one or more of the following: a pathological fracture, an extra-oral fistula or osteolysis extending to the inferior border [7]. The treatment modalities depend on the patient's symptoms and stage of the disease.

There are two major theories regarding the pathophysiology of BRONJ: the osteoclast-based 'inside-out' theory and the 'outside-in theory'. The first theory suggests that postulates the inhibition of osteoclastic activity and marked suppression of bone turnover, together with the spread of physiological micro-damage. After that local infection leads to bone death within the jaw, with subsequent exposure of bone. Bone exposure is a late event. The second theory suggests that a break in the oral mucosa leads to ingress of bacteria and local infection, which, coupled with poor bone remodeling, leads to bone death. BRONJ may result from a combination of these two mechanisms, in addition to hypovascularity, which plays an important role [8,9].

BRONJ is a challenging complication to treat, in terms of both disease control and quality of life [10]. The management of BRONJ has historically centered on minimizing symptoms and eliminating infection [11]. Medical treatments are routinely employed, together with conservative surgery of the exposed necrotic bone. However, in most cases, these do not result in long-term healing, and there is a risk of recurrence and disease progression. In a previous series, patients who had undergone previous unsuccessful bone debridement eventually required extensive mandibular resection owing to the progression of the underlying disease [10]. However, we recently demonstrated that properly planned bone debridement of the affected area and multilayer wound closure in BRONJ patients can result in new bone formation and relieve of the symptoms.

Some previous studies reported that a combination of necrotic bone curettage and platelet-rich plasma (PRP) seemed to be promising for the treatment of refractory BRONJ, with PRP apparently enhancing wound healing and bone maturation $[12,13]$. However, there is no consensus at pres- 
ent on whether PRP promotes soft tissue healing in BRONJ cases.

Plasma rich fibrin (PRF) as composed of densely thick fibrin networks, with activated platelets meshed among the fibrins [14]. In addition to the matrix scaffold, platelets provide and sustain the release of growth factors in the wound area [15]. Many growth factors, such as platelet-derived growth factor and transforming growth factor-b, that are released by PRF have been reported to stimulate the proliferation of gingival fibroblasts and to accelerate soft tissue healing [16]. However, more comprehensive studies are needed to understand the physiology and histology of soft tissue healing of PRF membranes.

Temporary interruption of bisphosphonate treatment can be considered in severe cases if the benefits outweigh the risks of skeletal-related events resulting from drug termination. Some patients may not be able to survive without bisphosphonate therapy. Others may develop further spontaneous fractures if bisphosphonates are discontinued. Improvements in BRONJ may not be observed with drug discontinuation because measurable levels of bisphosphonates may persist in bone for up to 12 after cessation of therapy [17]. Ozone therapy and hyperbaric oxygen therapy may be considered as treatment modalities for BRONJ. Ozone therapy increases blood flow and nutrition [18]. Hyperbaric oxygen has an angiogenic effect [19]. These modalities appear to be promising treatment options for osteonecrosis.

In conclusion, there are many protocols, guidelines, and suggestions on the management of BONJ. In most patients, a conservative approach with minimal local intervention, if necessary, seems to be appropriate, with extensive debridement of necrotic bone when this fails. In a small number of cases where other interventions fail or a pathological fracture develops, radical resection of bone and reconstruction may be required.

\section{REFERENCES}

1. Pit JV, Joel JO, Alice KM. Surgical treatment of bisphosphonate-associated osteonecrosis of the jaw. J Cranio Maxill Surg 2012;40:719-725.

2. Rathan MS, Gary MM. Bisphosphonate induced osteonecrosis of the mandible. Eur $\mathrm{J}$ Radiology Extra 2008;66:9-11.

3. Tomoaki S, Mutsumi M, Ryouji T. Bisphosphonate-related osteonecrosis of the jaw successfully treated with surgical resection and its histopathological features: A longterm follow-up report. J Oral Maxill Surg Pathol Med 2014;275:4-8.
4. Robert E. M. Pamidronate (Aredia) and zoledronate (Zometa) induced avascular necrosis of the jaws: a growing epidemic. J Oral Maxill Surg 2003;6:1115-1118.

5. Robert EM, Yoh S, Michel F, Vishtasb B. Bisphosphonate-induced exposed bone (osteonecrosis/osteopetrosis) of the jaws: risk factors, recognition, prevention, and treatment: J Oral Maxill Surg 2005;63:1567-1575.

6. Cesar AM. Bisphosphanates and oral cavity avascular bone necrosis: J Clin Oncol 2003;21:4253-4254.

7. American Association of Oral and Maxillofacial Surgeons. Position paperon bisphosphonate-related osteonecrosis of the jaws; 2006. Available at: http://www.aaoms. org/docs/position papers/osteonecrosis.pdf.

8. Cesar AM, Michael AS, Linda SE. Bisphosphonateassociated osteonecrosis: a long-term complication of bisphosphonate treatment: Lancet Oncol 2006;7:508514.

9. Ian RR. Osteonecrosis of the jaw - Who gets it, and why? Bone 2009;44:4-10.

10. PF Nocini, G Saia, G Bettini. Vascularized fibula flap reconstruction of the mandible in bisphosphonate-related osteonecrosis. The J Cancer Surg 2009;35:373-379.

11. Lerman MA, Xie W, Treister NS. Conservative management of bisphosphonate-related osteonecrosis of the jaws Staging and treatment outcomes. Oral Oncol 2013;49:977-983.

12. Curi MM, Cossolin GS, Koga DH. Bisphosphonate-related osteonecrosis of the jaws-An initial case series report of treatment combining partial bone resection and autologous platelet-rich plasma. J Oral Maxill Surg 2011;69:2465-2472.

13. Lee CY, David T, Nishime M. Use of platelet- rich plasma in the management of oral bisphosphonate-associated osteonecrosis of the jaw: A report of 2 cases. J Oral Implantol 2007;32:371-382.

14. Pripatnanont $P$, Nuntanaranont $T$, Vongvatcharanon $S$, et al. The primacy of platelet-rich fibrin on bone regeneration of various grafts in rabbit's calvarial defects. J Cranio Maxill Surg 2013;41:191-200.

15. Dhoan $D M J$, Choukroun $A D$, et al. Platelet-rich fibrin (PRF): A second-generation platelet concentrate. Part III: Leucocyte activation: A new feature for platelet concentrate? Oral Surgery Oral Med Oral Pathol Oral Radiol Endod 2006;101:51-55.

16. Dhoan DMJ, Ehrenfest GM, de Peppo P, et al. Slow release of growth factors and thrombospondin-1 in Choukroun's platelet-rich fibrin (PRF): A gold standard to achieve for all surgical platelet concentrates technologies. Growth Factors 2009;27:63-69.

17. Lin JH, Russell G, Gertz B. Pharmacokinetics of alendronate: an overview. Int J Clin Pract Suppl 1999;101:1826.

18. Agrillo A, Lingari C, Filiaci F, et al. Ozone Therapy in the Treatment of Avascular Bisphosphonate-Related Jaw Osteonecrosis. J Craniofac Surg 2007;18:1071-1075.

19. Marx RE. Oral and Intravenous BisphosphonatesInduced Osteonecrosis of the Jaws: History, etiology, prevention and treatment. Hanover Park: Quintessence Books. 2006. 